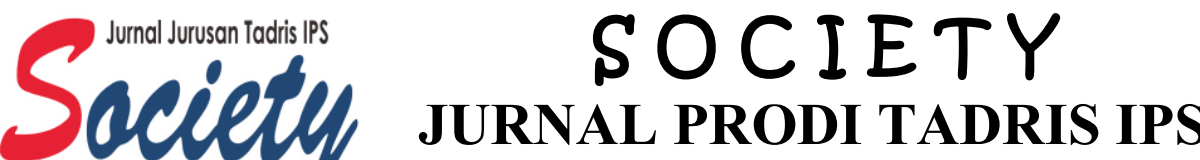

Volume 11, Nomor 1, Juni 2020

ISSN (p) : 2087-0493, ISSN (e) : 2715-5994

\section{STUDI PENYIMPANGAN SOSIAL PADA REMAJA DI DUSUN TOLOT-TOLOT DESA GAPURA KECAMATAN PUJUT KABUPATEN LOMBOK TENGAH}

\author{
Muh Zainur Rahman ${ }^{1)}$, Miftahur Rohmah ${ }^{2)}$, Nurin Rochayati ${ }^{3)}$ \\ ${ }^{1)^{*}}$ Tadris IPS FTK UIN Mataram,JL Gajah Mada No. 100, Mataram NTB, Indonesia, \\ Email: inoenk379@gmail.com \\ ${ }^{2)}$ Pendidikan Geografi FKIP Universitas Muhammadiyah Mataram,JL KH Ahmad Dahlan \\ Pagesangan, Mataram NTB,Indonesia , \\ ${ }^{3)}$ Pendidikan Geografi FKIP Universitas Muhammadiyah Mataram,Jl KH Ahmad Dahlan Pagesangan, \\ Mataram NTB, Indonesia Negara.
}

Diterima 15 April 2020 --- Disetujui 18 Mei 2020 --- Dipublikasikan 30 Juni 2020

\begin{abstract}
ABSTRAK
Penyimpangan sosial pada remaja memicu kepada kasus pergaulan bebas di kalangan remaja dan telah mencapai titik ke khawatiran yang cukup parah. Perilaku menyimpang merupakan hasil dari proses sosialisasi yang tidak sempurna. Kelompok yang paling rentan dalam proses perilaku menyimpang yaitu para remaja. Sesuai dengan permasalahan yang dikemukakan sebelumnya maka fokus penelitian ditekankan untuk mengetahui bentuk-bentuk penyimpangan sosial pada remaja di dusun tolot-tolot dan fungsi orangtua dalam menanggulangi penyimpangan sosial. Teknik pengumpulan data dan pengolahan data dalam penelitian kualitatif deskriptif dapat dilakukan dalam berbagai bentuk yaitu melalui observasi, wawancara dan dokumentasi. Teknik analisa data yang digunakan dalam penelitian ini berpatokan pada penelitian kualitatif deskriptif untuk itu peneliti menentukan informan sebanyak 10 informan yang terdiri dari 5 remaja yang melakukan perilaku menyimpang dan 5 Orangtua yang memilki anak remaja.

Hasil penelitian secara ringkas menunjukkan bahwa Bentuk-bentuk perilaku menyimpang di kalangan remaja yang ada di dusun tolot-tolot yaitu: seperti kenakalan remaja (pergi keluar rumah tanpa pamit, pulang sampai larut-larut malam), merokok, minum-minuman keras, kebut-kebutan, bermain game berlebihan, dll. Peran dan fungsi keluarga sangatlah berpengaruh bagi kehidupan anak remaja mereka apalagi di umur remaja adalah umur yang sangat rentan dengan perilaku menyimpang dan yang mempunyai peran sangat penting untuk menanggulangi perilaku menyimpang adalah orang tua.
\end{abstract}

Kata kunci: Penyimpangan Sosial, Remaja

\section{A. PENDAHULUAN}

Pada saat ini bangsa Indonesia telah dihadapkan dengan berbagai permasalahan yang sangat kompleks baik secara internal maupun eksternal, barangkali dapat kita bayangkan seandainya bangsa ini dipimpin oleh generasi muda atau anak bangsa yang malas, tidak bermoral, dan sifat yang tidak terpuji, maka bangsa ini akan menjadi bangsa yang terbelakang, jauh tertinggal dari negara-negara lainnya.

Menurut Robert M.Z. Lawang, penyimpangan adalah tindakan yang menyimpang dari norma- 
norma yang berlaku dalam suatu sistem sosial dan menimbulkan usaha dari pihak berwenang untuk memperbaiki perilaku yang menyimpang/normal. Sedangkan Paul B. Horton, berpendapat bahwa setiap perilaku yang dinyatakan sebagai pelanggaran terhadap norma-norma kelompok atau masyarakat.

Penyimpangan adalah konsep masalah sosial berkaitan dengan pelanggaran norma artinya sesuatu itu dianggap sebagai masalah sosial karena menyangkut hubungan manusia dengan nilai-nilai dan merupakan gangguan terhadap tujuan kehidupan masyarakat. Masalah sosial atau social problems ialah setiap keadaan yang dianggap ancaman bagi masyarakat sebagai suatu keadaan yang tak di kehendaki, tak dapat ditoleransi, atau dianggap ancaman bagi masyarakat. Penyimpangan sosisal atau perilaku menyimpang, sadar atau tidak sadar pernah kita alami atau kita lakukan. Penyimpangan sosial dapat terjadi dimanapun dan dilakukan oleh siapapun. Sejauh mana penyimpangan itu terjadi, besar atau kecil, dalam skala luas atau sempit tentu akan berakibat terganggunya keseimbangan kehidupan dalam masyarakat. Suatu perilaku dianggap menyimpang apabila tidak sesuai dengan nilai-nilai dan norma-norma sosial yang berlaku dalam masyarakat atau dengan kata lain penyimpangan (deviation) adalah segala macam pola perilaku yang tidak berhasil menyesuaikan diri (conformity) terhadap kehendak masyarakat. Penyimpang merupakan sisi negative dari bentuk perilaku positif, karena perilaku positif akan memberikan suasana kenyamanan dan keaamanan bagi masyarakat.

Di kalangan remaja sering dijumpai adanya perilaku yang menyimpang. Perilaku menyimpang merupakan hasil dari proses sosialisasi yang tidak sempurna. Kelompok yang paling rentan dalam proses perilaku menyimpang yaitu para remaja. Hal ini wajar terjadi tidak lain karena mereka memiliki karakteristik tersendiri yang unik, yaitu dalam masa-masa labil, atau sedang pada taraf pencarian identitas, yang mengalami masa transisi dari masa remaja menuju status dewasa, dan sebagainya.

Masa remaja awal merupakan masa transisi, dimana usianya berkisar diantara 13 sampai 16 atau 17 tahun dan akhir masa remaja bermula dari 16 atau 17 tahun bahkan sampai 18 tahun, yaitu usia matang secara hukum, dengan demikian akhir masa remaja merupakan periode yang sangat singkat (Hurlock, 2000). Pada masa transisi tersebut kemungkinan dapat menimbulkan masa krisis, dengan ditandai dengan kecendrungan munculnya perilaku menyimpang. Pada kondisi tertentu perilaku menyimpang terseut akan menjadi perilaku yang menggangggu (Ekowati,1993). Melihat kondisi tersebut apabila didukung oleh lingkungan yang kurang kondusif dan sifat kepribadian yang kurang baik akan menjadi pemicu timbulnya berbagai penyimpangn perilaku dan perbuatanperbuatan negatif yang melanggar aturan dan norma yang ada dimasyarakat.

Berdasarkan hasil survei awal, yang peneliti amati adalah bahwa di dusun Tolot-tolot penyimpangan sosial pada remaja memicu kepada kasus pergaulan bebas di kalangan remaja dan telah mencapai titik ke khawatiran yang cukup parah.Mengingat pentingnya peranan remaja sebagai generasi muda bagi masa depan bangsa maka masalah tersebut mendorong saya untuk melakukan penelitian terhadap remaja yang ada di 
dusun tolot-tolot, karena para remaja masih mempunyai masa depan yang panjang. Dengan demikian saya dapat melihat lebih dekat bagaimana peran orang tua dalam kehidupan anaknya terlebih khusus anak yang masih remaja.

\section{Penelitian Yang Relevan}

1. Penelitian yang dilakukan oleh Iis Susanti (2015) dengan judul Perilaku menyimpang dikalangan remaja pada masyarakat karangmojo pilandaan jombang. Skripsi Fakultas Ilmu Sosial Universitas Negeri Surabaya. Jenis penelitian yang gunakan adalah penelitian kualitatif yang menggunakan pendekatan fenomenologi, menggunakan teori sosialisasi, kontrol sosial dan labelling. Hasil dari penelitiannya adalah bahwa bentuk-bentuk penyimpangan di kalangan remaja pada desa Karangmojo termasuk dalam perilaku menyimpang yang cukup berat, yaitu terdapat perilaku menyimpang yang melanggar hukum. Adapun perilaku tersebut antara lain:

a. Seks bebas. Sosisalisasi yang tidak sempurna juga merupakan suatu pemicu terjadinya seks bebas pada remaja. Kemampuan seseorang menyerap nilai agama dan pendidikan dari orangtua juga sangat penting untuk melindungi diri seseorang dari perbuatan yang negatif. Selain itu juga seks bebas juga dilatarbelakangi oleh faktor lingkungan, terutama lingkungan bermain. Seorang remaja akan cenderung terpengaruh teman sepermainanya jika teman tersebut merupakan salah seorang pelaku seks bebas. Para remaja pada desa Karangmojo sebagian besar telah terpengaruh dan telah melakukan seks bebas meskipun masih duduk di bangku SMP.

b. Prostitusi. Tindakan prostitusi pada masyarakat ini juga disebabkan karena proses sosialisasi yang tidak sempurna dimana mereka cenderung belajar tindakan menyimpang tersebut dari keluarganya sendiri terutama orangtua. Dalam kasus yang ditemukan prostitusi terjadi justru karena dorongan dari orangtua mereka karena keadaan ekonomi yang pas-pasan. Tanpa mengelak dan tanpa berusaha mencari pekerjaan lain akhirnya mereka pun bekerja sebagai PSK.

c. Miras dan Narkoba. Pada masyarakat khususnya para remaja di Desa Karangmojo ternyata masih banyak sekali yang kecanduan dengan miras dan narkoba. Mereka seringkali berkumpul dengan teman-teman sebayanya bermain billiard dan akhirnya mabuk-mabukan bahkan bukan hanya terjadi pada remaja saja namun banyak juga bapak-bapak yang ikut bermain dan berujung mabuk.

2. Peneliti yang dilakukan oleh Anugrah Israk (2016) dengan judul Perilaku menyimpang pada kalangan remaja (studi kasus : pelaku balapan liar kalangan remaja di daerah kijang). Skripsi FISIPOL Universitas Maritim Raja Ali Haji, jenis penelitian yang digunakan dalam penelitian ini, yaitu berupa penelitian kualitatif, Penelitian ini bertujuan untuk mengetahui fenomena dari balapan liar yang terjadi pada kalangan remaja. Hasil dari studinya penelitian melihat bahwa Balapan liar akhir-akhir ini semakin marakterjadi di Indonesia yang tersebar diseluruh penjuru daerah. Pengaruh dariglobalisasi dan pergaulan membuat anak-anak remaja ini terlibat dalam aksibalapan liar dijalanan. Mayoritas pelaku balapan yang terlibat dalam aksibalapan liar ini semuanya masih berseragam sekolah.Masa remaja merupakan masa yang sangat penting bagi pembentukanidentitas diri. Karena kenakalan remaja merupakan suatu hal yang bisa sajaterjadi pada setiap anak muda yang masih berseragam 
sekolah atau berstatuspelajar. Tidak jarang dari kegiatan yang mereka lakukan dimulai dari rasa isengdan mencoba hal-hal baru yang menurut mereka adalah sesuatu hal menantangtanpa memikirkan resiko dari balapan liar tersebut.Perhatian dan pengawasan dari orang tua sangat diperlukan, sehingga anak tidak terjerumus dalam aksi balapan liar. Peranan dari orang tuamerupakan hal yang terpenting untuk memberikan contoh yang baik terhadapanak. Sehingga pola bimbingan orang tua akan membentuk jati dirinya, yangdapat memahami dan mengerti bagaimana yang seharusnya dilakukan.

Adapun persamaan peneliti terdahulu dengan penelitian yang sekarang yakni sama-sama melakukan penelitian tentang penyimpangan sosial dalam kaitannya dengan kenakalan remaja, salah satu dari sekian banyak masalah sosial yang semakin merebak pada waktu sekarang ini.Kenakalan remaja dalam studi masalah sosial dapat dikategorikan kedalam penyimpangan sosial. Penyimpangan Perilaku remaja dapat juga disebut dengan kenakalan remaja adalah suatu perbuatan yang melanggar norma, aturan atau hukum dalam masyarakat yang dilakukan pada usia remaja atau transisi masa anak-anak dan dewasa, secara tidak langsung hal tersebut merupakan bentuk penyimpangan sosial.

Adapun peneliti terdahulu dengan penelitian sekarang yakni penelitian terdahulu meneliti tentang Penelitian yang di lakukan oleh Iis Susanti (2015) dengan judul Perilaku menyimpang dikalangan remaja pada masyarakat karangmojo pilandaan jombang. Sedangkan penelitian sekarang meneliti tentang Studi Penyimpangan Sosial Pada Anak Usia 13-18 Di
Dusun Tolot-Tolot Desa Gapura Kecamatan Pujut Kabupaten Lombok Tengah dan tempat penelitian yang berbeda (Iis Susanti, 2015).

\section{Rancangan Penelitian}

Dalam melakukan penelitian ini, penulis menggunakan metode penelitian kualitatif, karena data yang akan diperoleh dilapangan lebih banyak bersifat informasi dan keterangan bukan dalam bentuk simpulan atau angka yang di peroleh dari berbagai informasi atau masyarakat yang berada di sekitar lokasi terkait penelitian yang dilakukan

Penelitian kualitatif adalah jenis penelitian yang mengungkapkan fakta, keadaan, fenomena dan keadaan yang terjadi saat peneliti berjalan dan menyuguhkan apa adanya dengan menggunakan kalimat. Kriteria data dalam penelitian kualitatif adalah data yang pasti atau data yang sebenarnya terjadi sebagaimana adanya yang mengandung makna. Metode penelitian ini gunakan untuk mendapatkan data yang mendalam, suatu data yang memgandug makna. Makna adalah data yang sebenarnya, data yang pasti yang merupakan suatu nilai dibalik data yang tampak. Oleh karena itu, dalam penelitian kualitatif tidak menekankan pada generalisasi,tetapi lebih menekankan pada makna. Generalisasi dalam penelitian kualitatif dinamakan transferability, artinya hasil penelitian tersebut dapat digunakan di tempat lain, mana kala tempat tersebut memiliki karakteristik yang tidak jauh berbeda (Sugiyono, 2018:08-09).

Penelitian kualitatif dimaksud untuk mengungkapkan dan memahami keyatankenyatan yang terjadi dilapangan sebagaimana adanya. Melalui penelitian kualitatif akan lebih luas dan mendalam mengungkapkan kajian tentang penelitian tersebut. Jenis pendekatan 
penelitian yang digunakan dalam penelitian ini adalah kualitatif. Alasan penggunaan pendekatan kualitatif yaitu selain menggunakan instrument yang berpedoman wawancara, sekaligus penelitian sebagai instrument untuk mengetahui asumsi-asumsi kultural yang berlaku dilokasi penelitian melalui observasi langsung.

\section{Lokasi Penelitian}

Lokasi yang dijadikan objek dalam penelitian ini adalah Dusun Tolot-tolot Desa Gapura Kecamatan Pujut Kabupaten Lombok Tengah. Lokasi ini dipilih karena mengingat pentingnya peranan remaja sebagai generasi muda bagi masa depan bangsa maka dari itu para remaja masih mempunyai masa depan yang panjang sehingga menarik untuk dijadikan lokasi penelitian, selain ini juga pemilihan daerah ini berdasarkan pertimbangan bahwa didaerah ini terdapat berbagai macam penyimpangan sosial yang melanggar aturan dan norma yang ada dimasyarakat, sehingga memungkinkan peneliti untuk meneliti di lokasi tersebut.

\section{Teknik Penentuan Informan}

1. Random Sampling

Randomsampling adalah pegambilan sampel dari anggota populasi secara acak dan berstrata secara proporsional,dilakukan sampling ini apabila anggota populasinya heterogen (tidak sejenis). Random sampling ini dilakukan degan cara membuat lapisan-lapisan (strata), kemudian dari setiap lapisan diambil sejumlah subjek secara acak. Jumlah subjek dari setiap lapisan (strata) adalah sampel penelitian.

\section{Area Sampling}

Area sampling atau kluster sampling adalah teknik sampling yang dilakukan degan cara megambil wakil dari setiap wilayah geografis yang ada.Cluster Sampling disebut juga sampel kelompok dan bukan individi.

3. Purposive Sampling

Purposive sampling dikenal juga degan sampling pertimbagan. Purposive sampling ialah teknik sampling yang digunakan peneliti jika peneliti mempunyai pertimbagan-pertimbagan tertentu didalam pegambilan sampelnya atau penentuan sampel untuk tujuan tertentu. Oleh karena itu, sampel ini cocok untuk studi kasus yang mana aspek dari kasus tugal yang representantif diamati dan dianalisis.

4. Snowball Sampling

Snowball sampling yaitu teknik pegambilan sampel berdasarkan wawancara atau koreesponden.Metode ini meminta informasi dari sampel pertama untuk mendapatkan sampel berikutnya, demikian secara terus menerus hingga seluruh kebutuhan sampel penelitian dapat terpenuhi.

Dari ke empat penentuan informan diatas yang peneliti gunakan dalam pengambilan sampel penelitian ini menggunakan teknik snowball sampling, karena penelitian ini dapat dilakukan dengan cara mencari contoh sample dari populasi yang kita inginkan, kemudian dari sample yang didapat dimintai partisipasinya untuk memilih komunitasnya sebagai sample lagi. Seterusnya sehingga jumlah sample yang kita inginkan terpenuhi.Adapun yang dimaksud Snowball samplingmerupakan salah satu metode dalam pengambilan sample dari suatu populasi. Dimana snowball sampling ini adalah termasuk dalam teknik non-probability sampling (sample dengan probabilitas yang tidak sama). Untuk metode pengambilan sample seperti ini khusus digunakan untuk data-data yang bersifat komunitas dari 
subjektif responden/sample, atau dengan kata lain objek sample yang kita inginkan sangat langka dan bersifat mengelompok pada suatu Himpunan. Dengan kata lain snowball sampling metode pengambilan sampel dengan secara berantai (multi level).

Dengan pemilihan berakhir jika sudah terjadi pengulangan yaitu pada sampel bertujuan seperti ini jumlah sampel ditentukan oleh pertimbanganpertimbangan informasi yang diperlukan. Jika maksudnya memperluas informasi, dan jika tidak ada lagi informasi yang dapat dijaring, maka penarikan sampel sudah harus di akhiri. Jadi, kuncinya disini ialah jika sudah mulai terjadi pengulangan informasi, maka penarikan sampel sudah harus dihentikan. Dalam penelitian ini merupakan penelitian kualitatif maka peneliti menggunakan informan dan penetuan subjek penelitian. Sesuai dengan pendapat (sugiyono,2018:219). Sampel dalam penelitian kualitatif bukan dinamakan reponden, tetapi sebagai narasumber atau informasi dalam penelitian. Informan adalah orang yang di percaya dan dianggap lebih memahami tentang obyek yang akan diteliti. Fungsinya dimanfatkan untuk memberikan informasi tentang situasi dan kondisi objek penelitian. (Basrowi dan Suandi, 2008:86).

Jadi dalam penelitian ini, peneliti mengunakan informan sebagai subjek penelitian. Informan ada dua yaitu informan kunci dan informan biasa:

a. Informan kunci adalah informan yang mengetahui secara meluas permasalahan yang sedang diteliti, Informan yang dimaksud dalam penelitian ini adalah remaja itu sendiri.

b. Informan biasa adalah informan yang
ditentukan dengan dasar pertimbangan

mengetahui dan berhubungan dengan permasalahan penelitian tersebut, yaitu orang tua.

\section{Jenis Data dan Sumber Data}

\section{Jenis Data}

Jenis data dalam pelaksanaan penelitian pada hakekatnya dibagi menjadi dua, yaitu data kualitatif dan data kuantitatif.

a. Data kualitatif adalah data yang dinyatakan dalam bentuk kata, kalimat yang biasanya berhubungan dengan nilai. Misalnya tinggirendah, besar-kecil.

b. Data kuantitatif adalah data yang mengunakan statistik dalam penyajian data (Sugiyono, 2010:208)

Adapun jenis data yang dipergunakan dalam penelitian ini adalah jenis data kualitatif bukan kuantitatif, karena tidak berhubungan dengan angka-angka (statistik). Jenis data kualitatif adalah jenis data yang dinyatakan dalm bentuk kata-kata atau kalimat. Sumber data utama dalam penelitian kualitatif adalah kata-kata, dan tindakan, selebihnya adalah data tambahan seperti dokumen dan lain-lain.

\section{Sumber Data}

a. Data primer yaitu data yang diperoleh secara langsung di lapangan dengan sumber data yaitu responden dan informan dengan menggunakan teknik pengumpulan data observasi dan wawancara.

b. Data sekunder yaitu data yang diperoleh dari instansi yang terkait, berupa dokumen-dokumen, laporan-laporan dan buku-buku serta hasil penelitian ilmiah yang dianggap relevan dengan masalah dan tujuan penelitian.

\section{Teknik Pengumpulan Data}

Teknik pengumpulan data merupakan langkah yang paling utama dalam penelitian,karena tujan 
utama dari peneliti adalah untuk mendapatkan data. Tanpa mengetahui teknik pengumpulan data, maka penelitian tidak akan mendapatkan data yang memenuhi standar data yang ditetapkan.

Dalam penelitian ini mengumpulkan data yang berkaitan dengan judul penelitian yang akan dilaksanakan, penulis menggunakan teknik observasi, wawancara (Interview) dan dokumentasi.

\section{Instrumen Penelitian}

Dalam penelitian kualitatif, yang menjadi instrument atau alat penelitian adalah peneliti itu sendiri.oleh karena itu peneliti sebagai instrument juga harus "divalidasi" seberapa jauh penelitian kualitatif siap melakukan penelitian yang selanjutnya terjun ke lapangan. Validasi terhadap peneliti sebagai instrument meliputi validasi terhadap pemahaman metode penelitian kualitatif.Penguasaan wawasan terhadap bidang yang diteliti, kesiapan peneliti untuk memasuki obyek penelitian, baik secara akademik maupun logistiknya.Yang melakukan validasi adalah peneliti sendiri, melalui evaluasi diri seberapa jauh pemahaman terhadap metode kualitatif, penguasaan teori dan wawasan terhadap bidang yang diteliti, serta kesiapan dan bekal memasuki lapangan.Peneliti kualitatif sebagai human instrument, berfungsi menetapkan focus penelitian, memilih informan sebagai sumber data, melakukan pengumpulan data, menilai kualitas data, analisis data, menafsirkan data dan membuat kesimpulan atas temuannya.

Dalam penelitian ini, instrument utamanya adalah peneliti itu sendiri.adapun instrument pendukung untuk melengkapi datanya berupa: buku pedoman/buku panduan/buku catatan, bolpoin handphone (untuk video dan foto) (Sugiono, 2013:222).

\section{Teknik Analisis Data}

1. Reduksi Data (Data Reduction)

Mereduksi data berarti merangkum, memilih halhal yang pokok, memfokuskan pada hal-hal yang penting, dan dicari tema dan polanya, sebab data yang diperoleh dari lapangan jumlahnya cukup banyak dan perlu dicatat secara teliti dan rinci. Dengan melakukan reduksi data akan memberikan gambaran yang lebih jelas, mempermudah peneliti untuk melakukan pengumpulan data selanjutnya, dan mencarinya bila diperlukan. Reduksi data dapat dilakukan dengan bantuan komputer dengan memberikan kode pada aspek-aspek tertentu (Sugiyono, 2016: 247).

\section{Penyajian Data (Data Display)}

Setelah data direduksi, langkah selanjutnya adalah mendisplaykan data. Dalam penelitian kualitatif, penyajian data bisa dilakukan dalam bentuk uraian singkat, bagan, hubungan antar kategori, flowchart, dan sejenisnya. Yang paling sering digunakan untuk menyajikan data dalam penelitian kualitatif adalah dengan teks yang bersifat naratif (Sugiyono, 2016: 249).

\section{Penarikan kesimpulan/verifikasi (Conclusion} drawing)

Kesimpulan atau verifikasi dalam penelitian kualitatif adaah temuan baru yang sebelumnya belum pernah ada. Temuan dapat berupa deskripsi atau gambaran suatu obyek yang sebelumnya masih remang-remang atau gelap sehingga setelah diteliti menjadi jelas, dapat berupa hubungan kausal atau interaktif, hipotesis atau teori. Dalam penelitian ini, setelah peneliti mereduksi dan menyajikan data, selanjutnya 
peneliti dapat membuat kesimpulan dari hasil Desa Gapura juga memiliki 3 buah Sekolah penelitiannya.

Dasar, yaitu:

Untuk lebih jelasnya, berikut ini disajikan bagan

- SDN Barelantan

model interaktif dalam analisis data:

- SDN Tolot-tolot

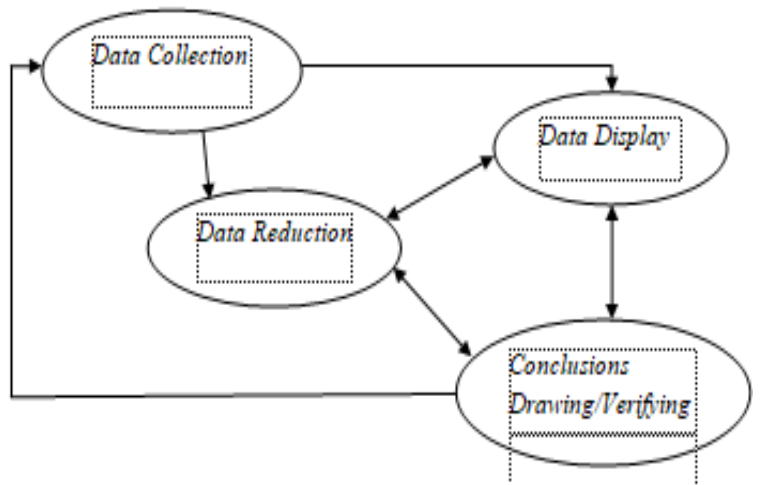

- SDN Dasan Ambon

Sumber : Jumlah Penduduk Desa Gapura

Dari tabel diatas terlihat bahwa jumlah penduduk perempuan lebih banyak dari penduduk perempuan di Desa Gapura Kecamatan Pujut.

\section{Letak Geografis dan Administratif Desa}

\section{Gapura}

\section{B. HASIL DAN PEMBAHASAN}

\section{Gambaran Umum Lokasi Penelitian}

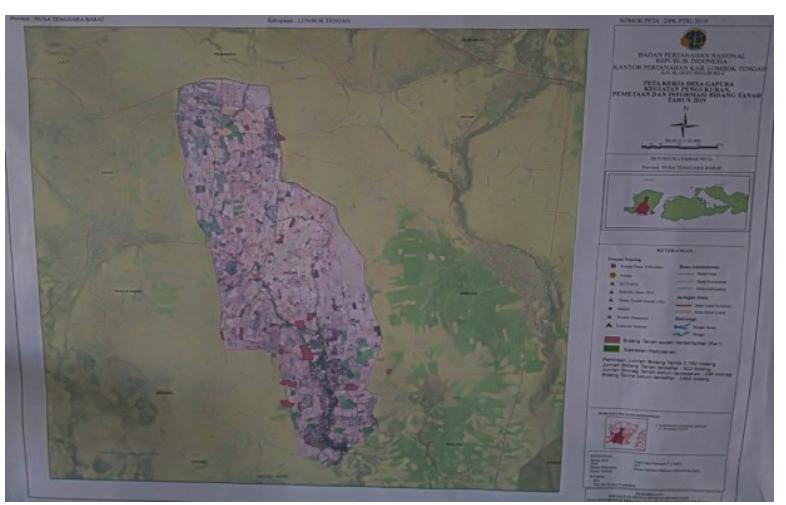

1. Letak Geografis

Letak Geografis Desa Gapura adalah sebagai berikut:
a. Sebelah Utara
: Desa Pejanggik
b. Sebelah Selatan : Desa Teruwai
c. Sebelah Timur : Desa Marong
d. Sebelah Barat
: Desa Kawo
2. Administratif

Desa Gapura merupakan salah satu wilayah di kecamatan Pujut yang mempunyai luas 447,1 Ha

Sumber: Peta Desa Gapura Kecamatan Pujut

Kabupaten Lombok Tengah dengan jumlah penduduk 3.081 jiwa Yang terdiri dari laki-laki 1.483 jiwa dan perempuan 1.598 Desa Gapura merupakan salah satu desa di jiwa dan terdiri dari 993 kepala keluarga. Untuk Kecamatan Pujut, Kabupaten Lombok Tengah, jelasnya dapat dilihat pada tabel 1 sebagai berikut Indonesia. Desa Gapura yang terletak diantara ini:

Desa Kawo, Segala Anyar, dan Teruwai ini memiliki potensi di sektor pertanian tembakau. Ini di buktikan dengan banyaknya lahan pertanian musiman yang ditanami tembakau pada saat musim panas.

Desa Gapura terdiri dari 3 dusun, yaitu:

- Dusun Barelantan

- Dusun Dasan Baru (Dasan Ambon)

- Dusun Tolot-tolot

\begin{tabular}{|c|c|c|}
\hline Tingkat Usia & Laki-laki & Perempuan \\
\hline $0-4$ Tahun & 96 & 115 \\
\hline 5-9 Tahun & 102 & 117 \\
\hline $10-14$ Tahun & 100 & 109 \\
\hline 15-19 Tahun & 106 & 112 \\
\hline $20-24$ Tahun & 105 & 110 \\
\hline $25-29$ Tahun & 89 & 98 \\
\hline $30-34$ Tahun & 81 & 107 \\
\hline $35-39$ Tahun & 81 & 84 \\
\hline $40-44$ Tahun & 105 & 109 \\
\hline $45-49$ Tahun & 98 & 97 \\
\hline $50-54$ Tahun & 100 & 96 \\
\hline $55-59$ Tahun & 103 & 95 \\
\hline
\end{tabular}




\begin{tabular}{|c|c|c|}
\hline $60-64$ Tahun & 92 & 119 \\
\hline $65-69$ Tahun & 88 & 81 \\
\hline $70-74$ Tahun & 94 & 114 \\
\hline 75- Ke atas & 43 & 35 \\
\hline Jumlah & 1.483 & 1.598 \\
\hline
\end{tabular}

Sumber : Jumlah Penduduk Desa Gapura

Dari tabel diatas terlihat bahwa jumlah penduduk perempuan lebih banyak dari penduduk perempuan di Desa Gapura Kecamatan Pujut.

\section{Tingat Pendidikan}

Pendidikan merupakan salah satu upaya untuk mencerdaskan kehidupan bangsa dalam meningkatkan Sumber Daya Manusia (SDM) sehingga pendidikan harus mendapat prioritas utama termaksud meningkatkan sarana dan prasarana. Tingkat pendidikan penduduk Desa Gapura sudah relatif baik yaitu dengan adanya sekolah SD, SMP, SMA yang terletak di Desa Gapura. Untuk lebih mengetahui tingkat pendidikan penduduk Desa Gapura dapat dilihat dalam tabel 2 dibawah ini sebagai berikut:

\begin{tabular}{|c|l|c|c|}
\hline \multirow{2}{*}{ No } & Tingkat pendidikan & \multicolumn{2}{|c|}{ Jenis kelamin } \\
\cline { 3 - 4 } & $\begin{array}{c}\text { laki- } \\
\text { laki }\end{array}$ & $\begin{array}{c}\text { Perem } \\
\text { puan }\end{array}$ \\
\hline 1 & $\begin{array}{l}\text { Usia 3-6 tahun yang } \\
\text { belum masuk TK }\end{array}$ & $\begin{array}{c}68 \\
\text { orang }\end{array}$ & $\begin{array}{c}95 \\
\text { orang }\end{array}$ \\
\hline 2 & $\begin{array}{l}\text { Usia 3-6 tahun yang } \\
\text { sedang TK/play } \\
\text { group orang }\end{array}$ & $\begin{array}{c}75 \\
\text { orang }\end{array}$ & $\begin{array}{c}101 \\
\text { orang }\end{array}$ \\
\hline 3 & $\begin{array}{l}\text { Usia 7-18 tahun yang } \\
\text { tidak pernah sekolah }\end{array}$ & $\begin{array}{c}3 \\
\text { orang }\end{array}$ & 1 orang \\
\hline 4 & $\begin{array}{l}\text { Usia 7-18 tahun yang } \\
\text { sedang sekolah }\end{array}$ & $\begin{array}{c}119 \\
\text { orang }\end{array}$ & $\begin{array}{c}175 \\
\text { orang }\end{array}$ \\
\hline 5 & $\begin{array}{l}\text { Usia 18-56 tahun } \\
\text { tidak pernah sekolah }\end{array}$ & $\begin{array}{c}65 \\
\text { orang }\end{array}$ & $\begin{array}{c}57 \\
\text { orang }\end{array}$ \\
\hline 6 & $\begin{array}{l}\text { Usia 18-56 tahun } \\
\text { pernah SD tetapi } \\
\text { tidak tamat }\end{array}$ & $\begin{array}{c}67 \\
\text { orang }\end{array}$ & $\begin{array}{c}19 \\
\text { orang }\end{array}$ \\
\hline 7 & $\begin{array}{l}\text { Tamat SD/sederajat } \\
\text { 136 }\end{array}$ & $\begin{array}{c}127 \\
\text { orang }\end{array}$ & orang \\
\hline 8 & $\begin{array}{l}\text { Usia 12-56 tahun } \\
\text { tidak tamat SLTP }\end{array}$ & $\begin{array}{c}44 \\
\text { orang }\end{array}$ & $\begin{array}{c}65 \\
\text { orang }\end{array}$ \\
\hline 9 & $\begin{array}{l}\text { Usia 18-56 tahun } \\
\text { tidak tamat SLTA }\end{array}$ & $\begin{array}{c}55 \\
\text { orang }\end{array}$ & 6 orang \\
\hline 10 & $\begin{array}{l}\text { Tamat SMP/sederajat } \\
\text { orang }\end{array}$ & $\begin{array}{l}29 \\
\text { orang }\end{array}$ \\
\hline
\end{tabular}

\begin{tabular}{|c|c|c|c|}
\hline 11 & $\begin{array}{l}\text { Tamat } \\
\text { SMA/sederajat }\end{array}$ & $\begin{array}{c}28 \\
\text { orang }\end{array}$ & $\begin{array}{c}129 \\
\text { orang }\end{array}$ \\
\hline 12 & Tamat D-1/sederajat & $\begin{array}{c}36 \\
\text { orang }\end{array}$ & $\begin{array}{c}30 \\
\text { orang }\end{array}$ \\
\hline 13 & Tamat D-2/sederajat & $\begin{array}{c}101 \\
\text { orang }\end{array}$ & $\begin{array}{c}21 \\
\text { orang }\end{array}$ \\
\hline 14 & Tamat D-3/sederajat & $\begin{array}{c}36 \\
\text { orang }\end{array}$ & $\begin{array}{c}42 \\
\text { orang }\end{array}$ \\
\hline 15 & Tamat S-1/sederajat & $\begin{array}{c}101 \\
\text { orang }\end{array}$ & $\begin{array}{c}121 \\
\text { orang }\end{array}$ \\
\hline & Jumlah & 963 & 1.176 \\
\hline & Jumlah Total & \multicolumn{2}{|c|}{2.139} \\
\hline
\end{tabular}

Sumber: Tingkat Pendidikan Penduduk Desa Gapura

\section{Mata Pencaharian}

Di Desa Gapura mayorits penduduknya bermata pencaharian sebagai petani dan buruh dalam bidang pertanian umumnya berupa petani pemilik, buruh tani dan orang tertentu yang di percayakan untuk menggarap sawahnya. Selain itu ada juga sebagai peternak, pedagang, Pegawai Negeri Sipil an lain-lain. Untuk lebih jelasnya tentang mata pencaharian masyarakat Desa Gapura lihat pada tabel 3 di bawah ini:

\begin{tabular}{|c|c|c|}
\hline $\begin{array}{c}\text { Jenis } \\
\text { Pekerjaan }\end{array}$ & Laki-laki & Perempuan \\
\hline Petani & 237 orang & 525 orang \\
\hline Buruh Tani & 250 orang & 437 orang \\
\hline Buruh Migran & 40 orang & 62 orang \\
\hline $\begin{array}{c}\text { Pegawai Negeri } \\
\text { Sipil }\end{array}$ & 60 orang & 35 orang \\
\hline $\begin{array}{c}\text { Pedagang } \\
\text { keliling }\end{array}$ & 4 orang & 7 orang \\
\hline Peternak & 44 orang & 22 orang \\
\hline Dokter swasta & 3 orang & 1 orang \\
\hline Perawat swasta & 15 orang & 35 orang \\
\hline $\begin{array}{c}\text { Bidan swasta } \\
\text { TNI }\end{array}$ & 15 orang & 27 orang \\
\hline $\begin{array}{c}\text { POLRI } \\
\text { Karyawan } \\
\text { perusahaan } \\
\text { swasta }\end{array}$ & 15 orang & 0 orang \\
\hline $\begin{array}{c}\text { Karyawan } \\
\text { perusahaan }\end{array}$ & 3 orang & 47 orang \\
\hline
\end{tabular}




\begin{tabular}{|c|c|c|}
\hline pemerintah & & \\
\hline Belum Bekerja & 19 orang & 7 orang \\
\hline Pelajar & 240 orang & 250 orang \\
\hline Perangkat Desa & 20 orang & 3 orang \\
\hline $\begin{array}{c}\text { Jumlah Total } \\
\text { Penduduk }\end{array}$ & $\mathbf{2 . 1 5 8}$ \\
\hline
\end{tabular}

Sumber : Mata Pencaharian Penduduk Desa Gapura

Dari tabel di atas dapat dilihat bahwa penduduk yang bekerja sejumlah 2.158 orang, sebagian penduduk Desa Gapura bermata pencaharian sebagai petani, selain jadi petani banyak juga penduduk yang bekerja sebagai peternak dan lainlain. Komoditi utama hasil pertanian penduduk Desa Gapura adalah Padi dan tembakau.

\section{Kehidupan Sosial dan Budaya}

Kehidupan sosial dan budaya masyarakat Desa Gapura Kecamatan Pujut Kabupaten Lombok Tengah selalu mengutamakan kehidupan berasaskan kehidupan yang bermasyarakat antara lain, gotong royong, silaturrahmi, serta saling menghormati antara yang satu dengan yang lain, bai sesame masyarakat di Desa Gapura maupun desa lain. Pendidikan juga merupakan sektor yang sangat penting karena pendieikan sering kali dijadikan barometer dalam melihat tingkat kemajuan suatu daerah.

\section{Potensi Desa Gapura}

a. Potensi sumber daya alam

Potensi sumber daya alam desa gapura meliputi pertanian, perkebunan, peternakan, perikanan, bahan galian, sumber daya air, kulitas udara, kebisingan, ruang publik/Taman, potensi wisata.

\section{b. Potensi sumber daya manusia}

Potensi sumber daya manusia desa gapura meliputi jumlah penduduk, usia, pendidikan, mata pencaharian pokok, agama/ aliran keprcayaan, kewarganegara, etnis, cacat mental dan fisik, tanaga kerja, kualitas angkatan kerja.

c. Potensi prasarana dan sarana

Potensi prasarana dan sarana desa gapura meliputi transportasi, komunikasi dan informasi, air bersih dan sanitasi, kondisi irigasi, sarana pemerintahan, lembaga kemasyarakatan desa/kelurahan, peribadatan, olah raga, kesehatan, energi dan penerangan, peribadatan, dan kebersihan.

\section{Pembahasan Hasil Penelitian}

Bentuk-bentuk penyimpangan sosial di kalangan remaja di Dusun Tolot-tolot Desa Gapura Kecamatan Pujut Kabupaten Lombok Tengah?

Penyimpangan sosial di kalangan remaja merupakan bagian dari kemerosotan moral dan kurangnya keberfungsian keluarga/orang tua dalam mendidik dan membesarkan anak-anaknya. Penyimpangan sosial dapat dibedakan menjadi dua yaitu dilihat berdasarkan kadar penyimpangan dan dilihat berdasarkan pelaku penyimpangannya

1. Bentuk Penyimpangan Sosial Berdasarkan Kadar Penyimpangan

a. Penyimpangan Primer

Penyimpangan primer disebut juga penyimpangan ringan. Para pelaku penyimpangan ini umumnya tidak menyadari bahwa dirinya melakukan penyimpangan. Penyimpangan primer dilakuakn tidak secara terus menerus (incidental saja) dan pada umumnya tidak begitu merugikan orang lain. Misalnya, mabuk saat pesta, menoret-coret tembok tetangga, ataupun balapan liar.

b. Penyimpangan Sekunder

Penyimpangan sekunder disebut juga penyimpangan berat. Umumnya perilaku penyimpangan dilakuakan oleh seseorang secara 
berulang-ulang dan terus menerus meskipun pelakunya sudah dikenai saksi. Bentuk penyimpangan ini mengarah pada tindak criminal, seperti pembunuhan, perampokan, dan pencurian. Penyimpangan jenis ini sangat merugikan orang lain sehingga pelakunya dapat dikenai sanksi hukum atau pidana.

2. Bentuk Penyimpangan Sosial Berdasarkan Pelaku Penyimpangannya

a. Penyimpangan Individu

Penyimpangan jenis ini dilakukan secara perorangan tanpa campur tangan orang lain. Contohnya seorang pejabat yang korupsi, oknum polisi yang melakukan pemerasan terhadap individu yang memiliki suatu kasus, suami atau istri yang selingkuh dan anakyang durhaka tehadap orangtua. Dilihat dari kadarnya penyimpangan perilaku yang bersfat ndividual menyebabkan pelakunya mendapat sebutan seperti pembandel, pembangkang, pelanggar, bahkan penjahat.

b. Penyimpangan Kelompok

Penyimpangan jenis ini dilakukan oleh beberapa orang yang secara bersama-sama melakukan tindakan yang menyimpang. Contohnya pesta narkoba yang dilakukan kelompok satu geng, perkelahian masal yang dilakukan antarkelompok suku ataupun pemberontakan. Penyimpangan kelompok biasanya sulit untuk dikendalikan karena kelompok-kelompok tersebut umumnya mempunyai nilai-nilai serta kaidah-kaidah sendiri yang berlaku bagi semua anggota kelompoknya.

c. Penyimpangan Campuran

Penyimpangan campuran diawali dari penyimpingan individu. Akan tetapi seiring dengan berjalannya waktu, pelaku penyimpang dapat memengaruhi orang lain sehingga ikut melakukan tindakan penyimpangan seperti halnya dirinya. Contoh penyimpangan campuran adalah sindikat narkoba, sindikat uang palsu, ataupun demonstrasi yang berkembang menjadi amuk massa.

Berdasarkan hasil penelitian di Dusun Tolot-tolot remaja yang melakukan penyimpangan sosial disebabkan karena keluarga yang broken home, ditinggal oleh salah satu orangtua dan orangtua yang sudah sibuk dengan urusan mereka masingmasing, sehingga untuk meluangkan waktu dan memperhatikan anak-anaknya sudah tidak ada lagi, sehingga mereka mudah terpengaruh dengan lingkungan-lingkungan yang tidak baik yang ada disekitar mereka.

Dan setelah peneliti amati bentuk-bentuk penyimpangan ang mencolok yang dilakkukan oleh remaja-remaja yang ada di dusun tolot-tolot ini antara lain:

1. Kenakalan Remaja

Kenakalan remaja ialah tindak perbuatan remaja yang bertentangan dengan hukum, agama, normanorma masyarakat sehingga akibatnya apat merugikan orang lain, mengganggu ketentraman umum dan juga merusak diri sendiri.

Seperti yang dijelaskan oleh $\mathrm{Bu}$ Arini "orang/anak-anak yang melanggar aturanaturan yang ada, jadi aturan itu banyak seperti aturan yang ada dimasyarakat, keluarga. Jadi entah itu disengaja maupun tidak disengaja, tapi kebanyakan untuk kenakakan remaja itu jelas disengaja dilakukannya. Kalok kenakalan remaja saat ini saya merasa sangat prihatin sekali, karena generasi saya dengan generasi sekarang ya jelas sangat berbeda. Kalau kenakalan remaja jaman saya dulu itu tidak kompleks seperti sekarang ini, jadi itilahnya sekarang ini 
kenakalan remaja itu lebih mencolok ke hal-hal yang berbahaya, dan lebih mengarah kepada kriminalitas".

Adapun Bentuk kenakalan remaja karena perceraian orang tua yang dialami pada subjek adalah menjadi pembohong, pemarah, bahkan melawan orang tua. Seperti halnya yang dijelaskan oleh zemy, 18 tahun, pelajar yaitu sebagai berikut:

"semenjak ibu an bapak saya bercerai, kehidupan saya sudah mulai berubah. Saya sering keluyuran kadang hampir gak pulang rumah, soalnya kalau sudah pulang bakalan dilarang buat main sama teman-teman. Pernah dimarahain tiap kali gak pulang rumah,namun tak pernah ku dengar katanya bahkan saya pernah melawan perkataannya sampai melukai hatinya. Itu bukan hal yang wajar tapi mau gimana lagi, gimana saya nggak melawan. Tanpa disadari orangtua saya sering menuntut anak-anaknya untuk selalu bersikap dan bertindak benar, hinggga hampir-hampir tak memberi tempat kepadanya untuk berbuat kesalahan. Bila orangtua menganggap bahwa setiap kesalahan adalah dosa yang harus diganjar dengan hukuman, maka anak-anaknya pun akan memilih untuk berbohong dan tiak mau mengakui kesalahan yan telah ku perbuat dengan jujur"

\section{Merokok dan Minum-minuman Keras}

Kebiasaan merokok dan minum-minuman keras sudah biasa dan bahkan sudah bukan hal yang lumrah dilakukan oleh para remaja yang ada di dusun Tolot-tolot ini, bahkan sampai setiap hari kegiatan ini mereka lakukan. Minuman keras atau beralkohol adalah minuman yang mengandung etanol, etanol adalah bahan psikoaktif dan konsumsinya menyebabkan penurunan kesadaran.
Awal mulanya remaja yang melakukan perilaku minuman keras pada umumnya adalah dengan mencoba baik itu diberi oleh temannya atau membeli sendiri minuman tersebut. Remaja yang meminum-minuman keras itu juga disebabkan oleh sifat remaja yang mudah terpengaruh oleh hal yang bersifat positif maupun bersifat negatif. Seperti halnya yang dijelaskan oleh Mamat, 17 tahun, pelajar sebagai berikut:

"Saya sudah merokok dan minum-minuman keras dengan teman-teman saya. Yang membuat saya melakukan hal ini kalau saya itu dikecewakan oleh pacar saya baru saya melakukan hal ini dan teman-teman bergaul saya pun begitu dan kami selalu melampiaskannya dengan cara merokok dan minum-minuman keras, tapi hal itu jarang kami lakukan, tidak selalu. Saya melakukan itu ditempat yang tersembunyi, sepi agar tidak dilihat oleh orang lain, kecuali teman dekat saya, kalau untuk berhenti saya tidak bisa jamin, karena saya melakukan hal itu ketika saya dapat masalah, baik masalah keluarga atau pacaran. Saya juga tidak tau kalau orangtua saya mengetahui kalau sya merokok dan minumminuman keras. Reaksi orangtua apabila mereka tau saya berbuat demikian, pasti mereka akan memarahi an bisa-bisa saya digantung, tetapikalau saya merokok atau minum-minuman keras sehabis itu pulang rumah, saya makan permen ulu atau makan apalah agar bau alkohol/rokok tiak tercium oleh mereka".

Selain itu, beberapa pendapat dari remaja yang secara tidak langsung mereka melakukan penyimpangan sosial. Sebagaimana yang diktakan oleh Firman, 16 tahun, pelajar sebagai berikut: 
"Saya merokok ini karena lihat teman, awalnya sih saya menolak untuk melakukan hal itu namun teman-teman saya terus-terusan mengejek saya (laki-laki kok tidak merokok) lalu saya mencicipi sedikit supaya tau rasanya, namun lamakelamaan jadi kecanduan. Saya tau merokok itu tidak baik untuk kesehatan, tapi saya masih saja menikmatinya untuk menghilangkan stress. Saya merasa sudah besar dan bebas tidak ada yang melarang. Apa yang saya lakukan tidak ada yang urus terserah dari saya mau lakukan apa. Apalagi jika ada yang membeli minum-minuman keras, pasti semuanya akan datang berkumpul dan tak ada yang berani larang”.

3. Kebut-kebutan

Kebut-kebutan yang dilakukan remaja dusun tolot-tolot cukup mersahkan masyarakat karena mereka rata-rata menggunakan kenalpot yang membuat telinga sakit, sehingga mengganggu masyarakat sekitar.

Seperti halnya yang dijelaskan oleh Beni yaitu:

"Yang membuat saya seing kebut-kebutan dijalan karena menurut saya tiak seru kalau membawa motor perlahan-lahan. Sebenarnya ada keinginan untuk berhenti,tapi hati saya masih belum siap kalau saya pensiun dari hal-hal tersebut. Mungkin orangtua saya tau dengan kelakuan saya, tapi mereka sudah tidak memperulikan saya lagi. Reaksi orangtua seandainya mereka tau mungkin mereka hanya diam, memang mereka selalu mengingatkan namun tiak mungkin mereka meliat bagaimana pergaulan saya seharihari. Mereka yang sok sibuk dengan urusan masing-masing sampai lupa sama anaknya sendiri, jujur saya juga merasa stress, karena mereka seakan-akan sudah tidak memperhatikan dan peduli dengan saya. Ini akibat karena mereka mengistimewakan anak perempuannya".

4. Bermain game berlebihan

Remaja-remaja yang mempunyai kegemaran bermain game berlebihan ini mempunyai kecenderungan untuk melakukan beberapa bentuk perilaku menyimpang disebabkan oleh faktor internal yaitu faktor yang berasal dari dalam diri remaja tersebut yaitu adanya kurangnya pengendalian emosi serta kelemahan dalam menegndalikan dorongan dan kecenderungan yang mengarah pada hal negatif dan faktor eksternal yaitu pengaruh dari teman sebaya yang mempunyai kesamaan hobi, kurangnya perhatian, pengawasan yang dilakukan orang tua, dan pengaruh lingkungan yang kurang baik.

Seperti halnya yang dijelaskan oleh Didit, 17 tahun, pengangguran

"Alasan saya bermain game tersebut karena adanya kemauan dari diri sendiri dan mengisi waktu kosong, banyak sekali waktu yang saya habiskan untuk bermain game, sehari biasanya saya menghabiskan waktu saya kurang lebih sepuluh jam an dalam sehari waktu yang saya habiskan untuk bermain game bahkan saya jarang tidur malam hanya karena bermain game. Mungkin saya sudah kecanduan bermain game sampai-sampai ketidakmampuan diri untuk mengendalikan hasrat untuk bermain, sehingga susah bahkan tidak mampu untuk menghentikan prilaku saya tersebut, Sebab bermain game selalu membuat saya lupa waktu karena menghabiskan waktu yang lama bahkan durasinya makin meningkat dari hari kehari”.
2 Peran dan fungsi orang tua dalam menanggulangi penyimpangan sosial di kalangan remaja di Dusun Tolot-tolot Desa 
Gapura Kecamatan Pujut Kabupaten Lombok Tengah?

Peran dan fungsi keluarga sangat berpengaruh bagi kehidupan anak remaja mereka apalagi di umur remaja adalah umur yang sangat rentan dengan perilaku menyimpang dan yang mempunyai peran sangat penting untuk menanggulangi perilaku menyimpang adalah orang tua. Fungsi keluarga adalah sebagai suatu pekerjaan atau tugas yang harus dilakukan didalam atau diluar keluarga. Sebab orangtua memiliki tanggung jawab untuk mendidik, mengasuh, dan membimbing anak-anaknya untuk mencapai tahapan tertentu yang menghantarkan anak untuk siap dalam kehidupan bermasyarakat. Seperti halnya yang dikatakan oleh Ibu emy, sebagai berikut:

"Peranan orangtua dalam keluarga mempunyai peranan besar dalam pembangunan masyarakat. Dalam rangka pelaksanan pendidikan nasional, peran orangtua semakin jelas dan penting terutama dalam penamaan sikap dan nilai atau norma-norma hiup bertetangga dan bermasyarakat. Jadi jelaslah orangtua mempunyai peran penting dalam tugas dan tanggung jawabnya terhadap seтиa anggota keluarga yaitu lebih bersifat pembentukan watak dan budi pekerti. Peran dan fungsi orangtua secara alamiah dan kodratnya harus melindungi dan menghidupi serta mendidik anaknya agar dapat hidup dengan layak dan mandiri setelah menjadi dewasa. Oleh karena itu tidak cukup hanya memberi makan minum dan pakaian saja kepada anak-anakya saja tetapi harus berusaha agar anaknya menjadi baik, pandai dan berguna bagi kehidupannya dimasyarakat kelak. Orangtua dituntut mengembangkan potensi yang dimiliki anaknya agar secara jasmani dan rohani dapat berkembang dengan selaras dan seimbang secara maksimal".

Tugas dan tanggung jawab tersebut tidaklah mudah terutama dalam mendidik anak. Minimnya pendidikan kepribadian, mental dan perhatian orangtua akibatnya dapat terbawa arus hal-hal negatif seperti penyalah gunaan obat-obat terlarang yang saat ini sedang berkembang dikota besar bahkan sampai kekampung-kampung yang akibatnya akan merusak mental dan masa depan anak, khususnya para pelajar yang diharapkan untuk menjadi generasi penerus bangsa yang sangat potensial dan produktif.

keluarga adalah unit pertama dan institusi pertama di dalam masyarakat dimana hubunganhubungan yang terdapat di dalamnya sebagian besar sifatnya hubungan langsung. Disitulah perkembangan individu dan disitulah terbentuknya tahap-tahap awal perkembangan dan mulai interaksi dengannya, ia memperoleh pengetahuan, keterampilan, minat dan sikap dalam hidup. Dalam keluarga orang tua sangat berperan sebab dalam kehidupan anak waktunya sebagian besar dihabiskan dalam lingkungan keluarga apalagi anak masih di bawah pengasuhan atau anak usia sekolah dasar, terutama peran seorang ibu.

Anak mulai bisa mengenyam dunia pendidikan dimulai dari kedua orang tua atau mulai pada masa kandungan, ayunan, berdiri, berjalan dan seterusnya. Orang tualah yang bertugas mendidik. Dalam hal ini (secara umum) baik potensi psikomotor, kognitif maupun potensi afektif, disamping itu orang tua juga harus memelihara jasmaniah mulai dari memberi makan dan penghidupan yang layak. Dan itu semua 
merupakan beban dan tanggung jawab Karena keluarga merupakan kesatuan terkecil sepenuhnya yang harus dipikul oleh orangtua. dalam masyarakat namun menempati kedudukan Demikianlah keluarga atau orang tua menjadi yang primer dan fundamental. Kualitas rumah faktor penting untuk mendidik anak-anaknya baik tangga atau kehidupan keluarga berperan dan dalam sudut tinjauan agama, sosial membentuk kepribadian remaja. Misalnya, rumah kemasyarakatan maupun tinjauan individu. tangga yang tidakutuh disebabkan oleh kematian Seperti halnya yang diungkapkan oleh Ibu Niya/45 tahun/IRT, yaitu:

"Hampir tiap hari saya nasehati anak saya sampai-sampai mulut saya berbusa pun tidak didenger, tiap kali dinasehati lebih kerasan anak saya, padahal niat saya cuma mau menasehati dia bukan untuk marahin dia. Pernah juga dia nggak pulang seharian bahkan sampai 1 minggu, Saya sampai nggak tidur mikirin anak saya yang tidak pulang kerumah, dan seisi rumah mencarinya susah, dan kami mendapatinya dirumah temannya. Cara saya untuk menanggulangi hal tersebut dengan cara membatasi untuk memberikan uang jajan, dulunya kalau dia minta uang selalu diberikan, tapi sekarang sudah tidak, nanti kalau memang ada keperluan yang memang di butuhkan baru dikasih. Karena kalau dikasih uang dia akan menggunakannya untuk jalan-jalan tidak tahu kemana, dan hanya akan membuat hawatir orangtua dan saya pun sudah habis pikir dengan kelakuannya seperti itu. Tindakan saya, saya hanya bisa menegur dan mengingatkan, karena dia sudah besar sudah tidak pantas untuk memukulinya. Tapi tiap kali saya berikan nasihat saya baru satu kata dia sudah seribu kata".

Dengan demikian dapat dinyatakan bahwa faktor keluarga merupakan faktor penyebab dari perilaku remaja itu sendiri, faktor keluarga memilik prosentase paling besar sebagai faktor penyebab penyimpangan sosial pada remaja. ayah atau ibu, perceraian orangtua, hidup terpisah, poligami, keluarga yang diliputi konflik disertai kekerasan, semua itumerupakan sumber yang bisa menjadi penyebab untuk memunculkan perilaku penympangan sosial. Selain itu anak kurang mendapat perhatian dan kasihsayang bahkan tuntunan pendidikan orangtua karena masing-masing sibuk dengan urusannya serta konflik batin sendiri. akibatnya anak menjadi bingung, risau, sedih, malu, sering diliputi rasaan dendam, benci sehingga anak menjadi kacau dan liar, dikemudian hari mereka mencari kompetensi diluar lingkungan keluarga.

Seperti yang dijelaskan oleh Bapak Adin/54/petani

"Tiap kali saya tegur dan saya pernah bertanya. Apa kamu merokok? Soalnya teman-temannya pernah bilang kalau dia sudah merokok, karena saya sibuk dengan pekerjaan saya dan jarang saya perhatiin apa yang anak saya lakukan diluarsana bahkan saya pernah dengar orangorang sekitar rumah pernah melihatnya merokook, tiap kali saya Tanya anak saya tapi dia selalu jawab tidak, karena dia berkata tidak maka saya tidak bisa berbuat apa-apa sebab saya tidak punya bukti kalau dia merokok, tapi saya selalu mengingatkan, kalau merokok itu tidak baik untuk kesehatan. Cara saya menanggulanginya yaitu dengan memberikan nasehat dan perhatian khusus, apa saja yang dia mau atau minta kalau memang ada uang pasti 
dikasih. Tindakan saya kalau saya mempergoki dia merokok pertama-tama saya tegur dan berikan peringatan dan kalau saya mempergokinya untuk yang ke dua kalinya, itu berarti dia memang tidak mau mendengar perkataan dan nasehat dari orangtuanya".

Lemahnya kontrol sosial merupakan salah satu penyebab tingginya tingkat perilaku menyimpang dikalangan remaja, terutama kontrol sosial dalam kelurga sangat berpengaruh terhadap perilaku anak. Keluarga sebagai dasar kepribadian dan pembentuk perilaku anak. Pengawasan dan bimbingan orang tua adalah hal terpenting untuk membuat anak menjadi apa nantinya ia dikemudian hari, pola bimbingan orangtua akan membentuk jati dirinya, dengan menjadi orang tua yang dapat memahami dan mengerti bagaimana yang seharusnya dilakukan terhadap anak, akan membuat anak pun menjadi nyaman. Perlu adanya ditanamkan nilai-nilai budi pekerti, kedisiplinan didalam keluarga mereka, dan orang tua harus mampu memberi teladan kepada anakanaknya. Karena peneliti melihat, orang tua dari para informan kurang memberikan pengawasan yang baik terhadap anak-anaknya.

Seperti yang telah diungkapkan oleh Ibu Nur, sebagai beriukt:

"anak saya sudah tidak bisa dinasehati lagi, setiap apa yang dia mau yang dia ingini mesti dituruti. Kadang saya sendiri sudah merasa jengkel dan masa bodo lagi apa yang mau diperbuatnya. Biar saja dia menuruti apa kata hatinya, entar nantinya dia akan tau sendiri resiko dan menanggung sendiri apa yang telah diperbuatnya".

\section{SIMPULAN DAN SARAN}

\section{Simpulan}

Berdasarkan hasil penelitian tentang penyimpangan sosial pada remaja yang ada di dusun tolot-tolot maka dapat saya simpulkan sebagai berikut:

- Menurut hasil yang saya dapat bahwa, Kurangnya peranan orang tua yang cenderung apatis terhadap anaknya untuk tidak mengikuti balapan liar dan pergaulan yang buruk merupakan masalah utama bagi orang tua dari pelaku. Kurangnya suasana harmonis dan rasa kekeluargaan terhadap anaknya, membuat remaja tersebut menjadi tidakterkendali dalam pengawasan orang tuanya.

Bentuk-bentuk perilaku menyimpang di kalangan remaja yang ada di dusun tolot-tolot yaitu: seperti kenakalan remaja (pergi keluar rumah tanpa pamit, pulang sampai larut-larut malam), merokok, minum-minuman keras, kebutkebutan, bermain game berlebihan, dll.

- Faktor pergeseran budaya dan sikap individualistis juga berpengaruh hal ini tercermin karena faktor berkemabangnya Teknologi dan Informasi juga berpengaruh karena dulunya mereka belum mengenal Internet, dan HP, dll. Tapi sekarag rata-rata anak remaja sudah memiliki dan mengetahui hal tersebut.

\section{Saran}

Bagi Remaja:

- Remaja hendaknya menghindari teman-teman yang sering atau suka melakukan perilaku menyimpang, karena perilaku menyimpang hanya akan membuat diri sendiri semakin mendapat berbagai masalah dan hanya akan merusak masa depan. 
- Apabila mendapat masalah jangan sungkansungkan untuk menceritakan kepada orang tua, dan apabila terdapat hal-hal yang mengganjal dalam keluarga cobalah untuk dibicarakan secara baik-baik dan dengan kekeluargaan untuk mencari jalan keluar.

\section{Bagi orang tua remaja.}

Peranan orang tua sangat diperlukan dengan mengarahkan si anak agar bisa lebih menghormati dan menghargai dirinya sendiri. Memberikan bimbingan dan pengawasan terhadap diri si anak akan lebih penting. Kebijaksanaan orang tua dalam menunjang proses sosialisasi anak-anak antara lain mengusahakan agar anak selalu berdekatan dengan orang tua, memberikan pengawasan dan pengendalian yang wajar, sehingga jiwa anak tidak merasa tertekan, mendorong anak membedakan yang baik dan yang salah, memperlakukan anak sebaik mungkin, dan menasihati anak jika melakukan kesalahan.

\section{DAFTAR PUSTAKA}

Afifuddin \& saebani 2009. Metode penelitian kualitatif. Bandung. Pustaka Setia.

Anugrah Israk (2016) dengan judul Perilaku menyimpang pada kalangan remaja (studi kasus : pelaku balapan liar kalangan remaja di daerah kijang). Skripsi FISIPOL Universitas Maritim Raja Ali Haji

Arikunto, Suharsimi. (2006). Prosedur Penelitian, Suatu Pendekatan Praktek. Jakarta: Rineka Cipta.

Darajat, Zakiah, 1974, Problema Remaja di Indonesia, Jakarta, Bulan Bintang.

Herabudin, (2015).Pengantar Sosiologi. Bandung: CV Pustaka Setia

http://www.duniapsikologi.com/remajapengertian-dan-definisinya/

http://www.pengertian ahli.com
http://Www.Ubb.Ac.Id/Menulengkap. Kenakalan Remaja/ Diakses pada 27 Mei 2016.

https://arenabelajar.com/penyimpangan-sosial/

https://berpendidikan.com

https://budisma,net/2015/10/faktor-penyebab-

penyimpangan -sosial.html

Iis Susanti, 2015. Perilaku menyimpang dikalangan remaja pada masyarakat karangmojo plandaan jombang.Skripsi.Fakultas sosial universitas negeri Surabaya.

Kartono, Kartini, (2003). Patologi Sosial 2 Kenakalan Remaja. Jakarta: Raja Grafindo Persada

Sarwono, Wirawan. 1997. Psikologi Remaja. Jakarta : PT Raja Grafindo Persada.

Setiawan, Marwan, (2015). Karakteristik Kriminalitas Anak \& Remaja. Ghalia Indonesia

Siahan, Jokie, (2009). Perilaku Menyimpang. PT Malta Printindo

Singgih D. Gunarsa, 2004, Psikologi Anak Remaja. Jakarta: Gunung Mulia

Soekanto , Soerjono.2007. Sosiologi Suatu Pengantar .Jakarta : PT Raja Grafindo.

Sugiyono.2013. Metodologi penelitian kuantitatif dan kualitatif dan $R \& D$ Bandung: Alfabeta

Sugiyono. 2016. Metodegi penelitian kuantitatif dan kualitatif dan $R \& D$ Bandung: Alfabeta

Sugiyono.2018. Metodelogi penelitian kuantitatif dan kualitatif dan $R \& D$ Bandung: Alfabeta 